\section{Ethnic inequalities in health: should we talk about implicit white supremacism?}

\author{
John Launer
}

If you live in the United States or the United Kingdom and have black or brown skin, your health is likely to be poorer on average than if you have white skin. You are also likely to receive healthcare of a lower standard. The statistics are dismal. ${ }^{1}$ Between 1991 and 2011, for example, Pakistani and Bangladeshi women in the UK had mortality rates $10 \%$ higher than white women. Long-term illness in men over 65 was reported by $69 \%$ of Pakistani men and $64 \%$ of Bangladeshi men, compared with $50 \%$ of white men. Women of the same ethnic groups reported even higher rates of long-term illness compared with white women. Black Caribbean men also had higher rates of long-term illness than white men. Similarly, a report from Public Health England in 2017 showed that children in black ethnic groups have higher than average levels of infant mortality. The black Caribbean group also had significantly worse levels of low birth weight and readiness for school. ${ }^{2}$

There are of course some variations and exceptions within ethnic disparities. People from certain minorities may do better than others in different respects, while specific individuals may manage to buck the trend. Some of the evidence is also complicated by the effects of social and educational deprivation, as well as poverty, which all intersect with ethnicity as determinants of health inequality, and spread beyond these groups. Having said that, ethnicity generally acts as an independent variable, augmenting other disadvantages. Racism and racial prejudice appear to be contributing factors here. ${ }^{3}$ These operate in many ways, but one of them is through racial biases in the provision of healthcare. ${ }^{4}$ In 'Just Medicine: A Cure for Racial Inequality in American Healthcare, Danya Bower Matthews, for example, cites studies showing how physicians with implicit biases as measured by psychological testing are more likely to prescribe pain medications or thrombolysis to white patients than to black ones. She argues that such unconscious biases held by healthcare professionals further

Correspondence to Dr John Launer, Postgraduate Medical Journal, London WC1H 9JP, UK; johnlauner@aol.com increase existing racial inequalities in health. ${ }^{5}$

The same kinds of implicit bias appear to play a part in the experiences of staff from ethnic minorities in health services. According to a report on Workforce Race Equality in the UK, ${ }^{6}$ white applicants within the National Health Service are 1.45 times more likely to be appointed to roles from shortlisting, compared with Black and Minority Ethnic (BAME) applicants. BAME staff are also 1.24 times relatively more likely to enter the formal disciplinary process compared with white staff. Within the medical profession, $1.1 \%$ of BAME doctors were referred to the General Medical Council (GMC) by employers during 2012-17 compared with $0.5 \%$ of white doctors. ${ }^{7}$ As the GMC report points out, the influences leading to these disproportionate rates of referral are 'multiple and intricately linked.' Risk factors for BAME doctors include their status as social 'outsiders', isolated or segregated working, lack of the support and feedback that would be given to 'insiders', and organisational cultures seeking a vulnerable individual to blame when something goes wrong.

\section{THE BIGGER PICTURE}

Two things are striking about all these statistics. One is how consistent they are in relation to both recipients and providers of healthcare. The other is that they are usually presented in a compartmentalised way, rather than as a single social or political phenomenon. It is rare to come across accounts that join up the dots, or explain that these are largely different manifestations of the same underlying causes. The also applies, broadly speaking, to the remedies prescribed for these problems. At the level of population health, researchers rightly point to the need for better housing, education and employment opportunities in the kinds of areas where poorer minorities live. ${ }^{8}$ Within the health service in the UK, staff are tested regularly on their knowledge of equality and diversity policies, and there are mandatory procedures aimed to prevent unfair job selection or promotion - even though these seem to be largely ineffective. ${ }^{9}$ Meanwhile, medical educators are now using imaginative ways to promote an awareness in their students of multiculturalism and social justice, in the hope that this may lead to more equitable care. ${ }^{10-12}$ Yet all these proposed fixes, and many others, are presented in isolation from each other. The discussion seems to be constrained by an unexpressed rule not to speak about the bigger picture.

I want to suggest that the unspoken bigger picture is in fact the long and enduring shadow of colonialism. People with black or brown skin who live in societies that are mostly populated by people with white skin, and largely ruled by them, are not there by random chance. Although the trajectory of each individual, family or group may have been entirely different, their forebears are all likely to have lived in remarkably similar circumstances. They were under the subjection of people who either came from very far away (like the English in India), or had the military and naval power to transport others from far away (like slave traders). In both cases, the ruling people also had the power to make their subjects do as they were told - in some instances relatively, but in others absolutely. One could elaborate this picture in many ways, and touch on aspects of history like the exploitation of natural resources and labour leading to pressure to emigrate, or mass displacements of people and extermination. Even without doing so, a common thread in all these ancestral experiences is the conviction possessed by their conquerors, in many cases backed up by spurious scientific theories, that they were innately superior to those they had conquered. ${ }^{13}$

\section{IMPLICIT WHITE SUPREMACISM}

In many ways, this colonial history remains with us. It persists most obviously in the lessons that our children are still taught, where they may learn 'how the west was won' in the US, or how the British Raj 'civilised' India, rather than seeing these through the eyes of the native inhabitants (and of most modern historians). Ironically, these narratives may be internalised by many of the descendants of those who were once occupied or enslaved. It continues to be echoed in the media, where the failings of politics in the west are depicted as aberrations, but portrayed as the norm in so-called 'less developed' countries. ${ }^{14} 15$ Beyond that, colonialism may sometimes be present in a reflex assumption of members of the dominant ethnic group that outsiders (especially if their ancestors originated from the southern hemisphere) have more to learn from white people than vice versa. Such 
attitudes, both psychological and physical, are not always passed on consciously. They are conveyed from generation to generation even without words, but they guide people as to whether to ask or not to ask certain questions, to listen or not to listen to the answers, and to decide what action to take.

Most of us rarely come across explicit white supremacism in as brutal a form as it existed previously, although in recent years it has been shocking to see it re-emerge publicly in a way that was unimaginable for a very long time. Yet implicit white supremacism may still be with us far more than we are willing to concede - at every level from the individual to the organisation and entire society. ${ }^{16}$ If we cannot now name it, help people to become aware of its pervasive nature, and address it explicitly, all our other efforts at addressing ethnic inequalities in health may only be tinkering at the margins.

Twitter John Launer @JohnLauner

Funding The authors have not declared a specific grant for this research from any funding agency in the public, commercial or not-for-profit sectors.

Competing interests None declared.

Patient consent for publication Not required.
Provenance and peer review Not commissioned; internally peer reviewed.

(C) Author(s) (or their employer(s)) 2020. No commercial re-use. See rights and permissions. Published by BMJ.

\section{Check for updates}

To cite Launer J. Postgrad Med J 2020;96:117-118.

Postgrad Med J 2020;96:117-118.

doi:10.1136/postgradmedj-2019-137295

\section{REFERENCES}

1 Bécares L. Which Ethic Groups Have the Poorest Health? Ethnic Health Inequalities 1991 to 2011. Manchester: Manchester University and Joseph Rowntree Foundation, 2013. Available: http:// hummedia.manchester.ac.uk/institutes/code/ briefingsupdated/which-ethnic-groups-have-thepoorest-health.pdf [Accessed 1 Nov 2019].

2 Public Health England. Public Health Outcomes Framework: Health equity report - focus on ethnicity. London: Public Health England, 2017. Available: https://assets.publishing.service.gov.uk/government/ uploads/system/uploads/attachment_data/file/733093/ PHOF_Health_Equity_Report.pdf [Accessed 1 Nov 2019].

3 Matthews D. The impact of ethnicity on health inequality. Nursing Times 2015;111:18-20.

4 Institute of Medicine. Unequal Treatment: Confronting racial and ethnic disparities in health care. Washington, DC: National Academy Press, 2002.

5 Matthew DB. Just Medicine: A Cure for Racial Inequality in American Healthcare. New York: NYU Press, 2015.

6 NHS Workforce Race Equality Standard. Data analysis report for NHS trusts, 2018. Available: https://www. england.nhs.uk/wp-content/uploads/2018/12/wres2018-report-v1.pdf [Accessed 1 Nov 2019].

7 General Medical Council. Fair to refer? reducing disproportionality in fitness to practise concerns reported to the GMC. London: general medical Council, 2019. Available: https://www.gmc-uk.org/-/media/ documents/fair-to-refer-report_pdf-79011677.pdf [Accessed 1 Nov 2019].

8 Marmot M. Fair Society, Health Lives: The Marmot review. Available: http://www.instituteofhealthequity. org/resources-reports/fair-society-healthy-lives-themarmot-review/fair-society-healthy-lives-full-reportpdf.pdf [Accessed 1 Nov 2019].

9 West M, Dawson J, Kaur M. Making the difference: diversity and inclusion in the NHS, London, Kings Fund, 2015. Available: https://www.kingsfund.org.uk/ publications/making-difference-diversity-inclusion-nhs [Accessed 1 Nov 2019].

10 Kumagai AK, Lypson ML. Beyond cultural competence: critical consciousness, social justice, and multicultural education. Academic Medicine 2009;84:782-7.

11 White AA, Logghe HJ, Goodenough DA, et al. Selfawareness and cultural identity as an effort to reduce bias in medicine. J Racial and Ethnic Health Disparities 2018:5:34-49.

12 Sukhera Jl. Bias in the Mirror: Exploring implicit bias in health professions education. Maastricht: Maastricht University Press, 2018.

13 Nazroo JY. Genetic, cultural or socioeconomic vulnerability? Explaining ethnic inequalities in health. In: Bury M, Gabe J, eds. The sociology of health and illness: A reader. Abingdon: Routledge, 2004.

14 Hickel J. The Divide: a brief guide to global inequality and its solutions. London: Windmill Books, 2018.

15 Chang H-J. 23 Things they don't tell you about Capitalism. London: Penguin, 2011.

16 Eddo-Lodge R. Why I'm no longer talking to white people about race. London: Bloomsbury, 2017. 